\title{
PENDAMPINGAN DUKUNGAN PSIKOLOGIS AWAL (DPA) PADA WALI MURID PAUD DALAM MENGHADAPI PEMBELAJARAN ONLINE DESA CURUGBARANG
}

\author{
Lulu Aulia Maulida, Eneng Liah Khoiriyah, Dede Imtihanudin, \\ Rihatuljannah, Asep Saefullah Kamali, Idris Supriadi, Badri Munawar \\ STKIP SYEKH MANSHUR \\ luluaulia33@gmail.com ${ }^{1}$
}

\begin{abstract}
Abstrak
Penelitian PKM ini bertujuan untuk memberikan pemahaman terkait Dukungan Psikologis Awal (DPA) kepada wali murid PAUD dalam menghadapi pembelajaran online di Desa Curugbarang agar dapat membantu mencegah dampak lebih buruk dan memberikan peluang bagi wali murid untuk mengembangkan kemampuan menghadapi situasi sulit serta melatihemosi wali murid dalam mendampingi anak belajar dan bermain selama masa pandemi dalam menghadapi pembelajaran online. Banyaknya berbagai tekanan dan situasi sulit pada orang tua pada masa pandemi Covid19 yang akan memengaruhi anak, termasuk yang masih berusia dini menjadi dasar pelaksanaan Pengabdian Kepada Masyarakat (PKM). Pelaksanaan PKM ini dilaksanakan secara tatap muka dengan tetap memperhatikan protokol kesehatan yang diikuti oleh 10 wali murid PAUD di Desa Curugbarang. Kegiatan PKM Pendampingan Dukungan Psikologis Awal (DPA) pada wali murid PAUD ini berjumlah tiga (3) tahap dengan waktu pelaksanaan yang berbeda. Metode yang digunakan dalam PKM ini adalah descrptive qualitative dengan proses pengambilan data melalui kuesioner, wawancara dan dokumentasi. Hasil yang diperoleh dari kegiatan PKM ini adalah sebagian wali murid sudah menerapkan langkah pertama DPA dan mampu memahami dan menerapkan langkah DPA yang selanjutnya.
\end{abstract}

Kata kunci: Pendampingan, Dukungan Psikologis Awal (DPA)

\begin{abstract}
This PKM research aims to provide an understanding of Early Psychological Support (DPA) to PAUD parents in dealing with online learning in Curugbarang Village in order to help prevent worse impacts and provide opportunities for parents to develop the ability to deal with difficult situations and train parents' emotions in mentoring children to learn and play during the pandemic in dealing with online learning. The number of various pressures and difficult situations on parents during the Covid-19 pandemic that will affect children, including those who are still early in the implementation of Community Service (PKM). The implementation of this PKM was carried out face-to-face while still paying attention to the health protocol which was followed by 10 PAUD guardians in Curugbarang Village. The PKM activity for Early Psychological Support (DPA) for PAUD guardians took place in three (3) different stages of implementation. The method used in this PKM is descriptive qualitative with the data collection process through questionnaires, interviews and documentation. The results obtained from this PKM activity are that some of the parents have implemented the first step of DPA and are able to understand and apply the next step of DPA
\end{abstract}

Keywords: Mentoring, Early Psychological Support (DPA)

Artikel disetujui tanggal:20 Nopember 2021

Corresponden Author Lulu Aulia Maulida email:Luluaulia33@gmail.com

DOI: $\underline{\text { http://dx.doi.org/10.31851/dedikasi.v4i2.6450 }}$ doi) 


\section{W/AHANA DEDIKASI}

PENDAHULUAN

Sejak World Health Organization (WHO) menyatakan Covid-19 sebagai Global Pandemic pada tanggal 11 Maret 2020 dan ditetapkannya Keputusan Presiden (Keppres) Nomor 12 Tahun 2020 tentang Penetapan Bencana Nonalam Penyebaran Corona Virus Disease 2019 (Covid-19) sebagai Bencana Nasional. Hal ini menyebabkan keamanan dan pertahanan dunia terserang, juga berdampak pada aktivitas sosial, pendidikan, ekonomi, dan politik di seluruh dunia. Pendidikan adalah salah satu bidang yang terkena dampak dari tersebarnya virus corona di Indonesia sehingga pemerintah melalui kementerian pendidikan dan kebudayaan Indonesia mengambil langkah cepat dengan melakukan antisipasi dini mengeluarkan Surat Edaran Mendikbud Nomor 4 Tahun 2020 yang mengatur aturan bagi anak sekolah yang belajar dari rumah (learn from home) dan bekerja dari rumah (work from home), termasuk guru yang bekerja di satuan PAUD. Bagi dunia pendidikan yang ada di Indonesia kondisi ini adalah hal yang tidak terduga bagi semua pihak, baik itu guru, orang tua, dan anak. Guru, orang tua, dan anak-anak tiba-tiba harus mencari cara agar proses belajar tetap berjalan, meski harus berdiam diri di rumah dalam waktu yang tidak tentu.

Dalam implementasinya, pelaksanaan pembelajaran online ini tidak selalu berjalan mulus, terutama dalam pendidikan anak usia dini (PAUD) masih banyak keluhan dari guru mengenai bagaimana cara penggunaan media daring seperti zoom, google classroom dan aplikasi lainnya, kesulitan dalam mengoperasikan komputer, internet yang tidak stabil, kesulitan dalam mengkomunikasikan pesan ke orangtua, kesulitan untuk menyusun perencanaan pembelajaran yang sederhana dan sesuai namun dapat diterapkan anak di rumah melalui orangtua, dan juga kesulitan guru dalam melakukan penilaian pembelajaran terhadap hasil belajar anak selama di rumah. Di sisi lainnya, keluhan pun datang dari pihak orangtua, yaitu kesulitan tidak biasa menggunakan teknologi digital untuk pembelajaran anak, kesulitan dalam mendampingi anak belajar di rumah karena belum memahami caranya, tidak mengerti maksud pesan yang diberikan guru, dan lain sebagainya. Itulah berbagai permasalahan yang muncul akibat dari pandemi Covid-19 yang mewabah dunia dan memaksa orang-orang melakukan hal di luar kebiasaan mereka selama ini (Muhammad, 2020).

Di masa pandemi Covid-19 ini, sebagian besar dari kita semua harus bekerja dari rumah (work from home) dan anak-anak harus belajar dari rumah (learn from home). Ini adalah masa yang sulit yang menyebabkan kekhawatiran tidak saja kesehatan fisik tetapi juga kesehatan mental atau jiwa. Bagi anak usia dini, kehadiran orang tua yang sepenuhnya berada di rumah seharusnya merupakan hal yang menyenangkan bagi mereka. Namun, yang terjadi tidak demikian. Orang tua menghadapi berbagai tekanan, seperti pendapatan berkurang, kesulitan bekerja di rumah, atau jenuh dengan situasi. Berbagai tekanan pada orang tua ini pada akhirnya dapat memengaruhi anak, termasuk anak usia dini. Orang tua yang mudah marah, bingung dan tidak 


\section{WAHANA DEDIKASI}

peduli akan menghadirkan suasana rumah yang tidak nyaman. Tentunya hal ini dapat mempengaruhi interaksi antar anggota keluarga, termasuk saat orang tua menemani anaknya belajar dan bermain di rumah. Jika keadaan ini terus berlanjut, maka akan mempengaruhi kesehatan mental seluruh anggota keluarga, termasuk anak usia dini.

Ini sesuai dengan hasil wawancara yang dikemukakan oleh wali murid PAUD di Desa Curugbarang yang menyatakan bahwa hilangnya pendapatan, ketidaksiapan membagi waktu antara bekerja di rumah dan mengurus rumah tangga, serta mendampingi belajar anak secara online membuatnya sangat tertekan dan marah pada situasi, yang akhirnya timbulah hubungan yang tidak harmonis antar anggota keluarga yang akan berdampak pada cara berkomunikasi dengan anak, sehingga anak merasa tidak nyaman dan bisa terhambat tumbuh kembangnya. Contohnya ketika anak menumpahkan air yang harusnya masalah tersebut dapat dibicarakan secara baik-baik dengan anak, malah menjadi masalah yang besar.

Dukungan Psikologis Awal (DPA) adalah suatu cara untuk membantu orang yang mengalami kesulitan, sehingga mereka merasa lebih tenang, aman, dan didukung untuk mengatasi situasi, masalah, atau tantangan yang sulit (Centre, 2020). DPA dapat dianalogikan atau disamakan sebagai Pertolongan Pertama Pada Kecelakaan (P3K) yang dapat dilakukan oleh semua orang untuk menyembuhkan luka fisik yang ringan, sedangkan DPA untuk luka batin atau jiwa yang ringan. DPA juga membantu mencegah situasi menjadi lebih memburuk dan dapat memberi orang tua kesempatan untuk mengembangkan kemampuan mereka untuk menghadapi situasi sulit (Kementerian Pendidikan dan Kebudayaan, 2020).

Dalam kehidupan sehari-hari baik itu di rumah maupun di lingkungan kerja, seringkali orang tua dihadapkan dengan berbagai macam situasi sulit. Situasi sulit ini dapat terjadi dalam konteks bencana alam dan bencana non-alam (pandemi Covid-19). Contohnya hubungan yang tidak harmonis antar anggota keluarga, kesibukkan pekerjaan, kerugian usaha, gagal usaha, kehilangan pekerjaan, pengurangan penghasilan, ketidaksiapan mendampingi belajar anak di rumah dan lain sebagainya. Lalu munculah reaksi atas situasi sulit tersebut seperti rasa tidak nyaman seperti panik, kecewa, jenuh, cemas, takut, sedih, mudah tersulut emosi seperti marah tanpa sebab, kelelahan fisik dan lain-lain. Yang akhirnya reaksi tersebut dapat memberikan dampak pada cara berinteraksi dengan anak dan anggota keluarga lainnya.

Ada tiga langkah DPA bagi orang tua, yaitu: (1) Mengenali dan memberikan perhatian, mengenali adanya perubahan yang tidak nyaman dan memberikan perhatian pada diri sendiri dan anggota keluarga lainnya. (2) Mendengarkan, mencermati dengan baik dengan cara mendengarkan apa yang terjadi dan dirasakan oleh diri sendiri serta anggota keluarga tanpa menyepelekan, menyalahkan dan mengkritik (3) Menghubungkan, ketika kedua langkah tidak cukup, orang tua perlu menghubungkan ke orang atau lembaga yang dinilai mampu membantu, misalnya saudara

\section{Copyright@Lulu Aulia Maulida}




\section{WAHANA DEDIKASI}

atau teman yang dekat dan dapat dipercaya, dokter, P2TP2A, psikolog, dan Puspaga (Kementerian Pendidikan dan Kebudayaan, 2020).

Tujuan dari kegiatan
pengabdian ini adalah untuk memberikan informasi dan keterampilan kepada guru dan orang tua tentang bagaimana mengelola banyak tekanan yang mereka alami selama masa sulit, terutama di saat pandemic melalui Dukungan Psikologis Awal (DPA). Keterampilan ini diharapkan agar akibat dari banyak tekanan tersebut tidak bertambah buruk dan mempengaruhi kesehatan jiwa seluruh anggota keluarga dan menghambat proses tumbuh kembang anak-anak yang masih berusia dini.

Berdasarkan tujuan kegiatan pengabdian di atas, makadilakukanlah kegiatan pengabdian kepada masyarakat yaitu Pendampingan Dukungan Psikologis Awal (DPA) pada Wali Murid PAUD dalam Menghadapi Pembelajaran Online di Desa Curugbarang.

\section{BAHAN DAN METODE}

Kegiatan pengabdian kepada masyarakat ini dilakukan dengan tiga tahap di hari yang berbeda secara tatap muka di PAUD Daru Al-Azkia Kp. Cimongkor Desa Curugbarang bersama 10 Wali Murid PAUD dengan tetap memperhatikan protokol kesehatan seperti pengaturan tempat duduk berjarak, menyiapkan tempat cuci tangan dan menggunakan masker. Prosedur pengumpulan data yang digunakan dalam kegiatan pengabdian ini adalah kuesioner, wawancara dan dokumentasi.

Tahapan yang dilakukan dalam kegiatan pengabdian kepada masyarakat sebagai berikut: a. Tahap 1

Tahap ini dilaksanakan pada hari Kamis, 26 Agustus 2021. Pada tahap ini dilakukan pembagian kuesioner kepada wali murid paud terkait cara memeriksa kondisi diri. Yaitu kondisi yang berhubungan dengan gejala, keluhan atau masalah tertentu yang mungkin dirasakan mengganggu selama 30 hari terakhir. Yang nantinya apabila wali murid mengalami 6 dari 20 gejala tersebut itu tandanya mereka membutuhkan dukungan psikologis awal dan akan ditindak lanjuti di tahap berikutnya.

b. Tahap 2

Tahap ini dilaksanakan pada hari Sabtu, 28 Agustus 2021. Tahap ini merupakan tahap lanjutan dari tahap satu, di mana dalam tahap ini yaitu melakukan sedikit pengenalan tentang Dukungan Psikologis Awal (DPA) dan wawancara berupa tanya jawab dengan wali murid terkait permasalahan yang terjadi selama menghadapi pembelajaran online.

c. Tahap 3

Tahap ini dilaksanakan pada hari Senin, 30 Agustus 2021. Pada tahap ini kegiatan yang dilakukan adalah membagikan poster dukungan psikologis awal dan dilanjutkan dengan menyampaikan materi lebih dalam seputar pemahaman dukungan psikologis awal (DPA) pada wali murid PAUD dan melakukan diskusi di mana setelah penyampaian materi selesai, wali murid diberikan kesempatan untuk memberikan pertanyaan terkait dengan materi.

\section{HASIL DAN PEMBAHASAN}

Hasil dari kegiatan pengabdian kepada masyarakat berupa Pendampingan Dukungan Psikologis Awal (DPA) pada Wali Murid PAUD 


\section{VAHANA DEDIKASI}

dalam Menghadapi Pembelajaran Online di Desa Curugbarang yang dilakukan secara tatap muka sebagai salah satu satu wujud dedikasi yang diperlukan masyarakat pada masa pandemi saat ini ini dengan tetap mematuhi protokol kesehatan.

Pelaksanaan kegiatan pendampingan dukungan psikologis awal pada wali murid PAUD ini menggunakan 3 tahapan, yaitu: (1) Membagikan kuesioner bertujuan untuk mengetahui kondisi diri para wali murid terhadap gejala yang dirasakan selama 30 hari terakhir, (2) Wawancara, hal ini bertujuan untuk mengetahui permasalahan yang terjadi selama menghadapi pembelajaran online, (3) Penjelasan materi, bertujuan untuk menyampaikan materi seputar pemahaman dukungan psikologis awal pada wali murid PAUD dalam menghadapi pembelajaran online.

Tahap pertama dalam membagikan kuesioner kepada wali murid PAUD, terdapat 20 butir soal pilihan ganda. Dalam kuesioner tersebut menekankan bagaimana cara wali murid dalam memeriksa kondisi diri yang berhubungan dengan gejala, keluhan atau masalah tertentu yang mungkin dirasakan mengganggu selama 30 hari terakhir. Yang nantinya apabila wali murid mengalami 6 dari 20 gejala tersebut itu tandanya mereka membutuhkan dukungan psikologis awal dan akan ditindak lanjuti ditahap berikutnya. Hasil dari tahap pertama ini membuktikan bahwa para wali murid PAUD membutuhkan dukungan psikologis awal, terlihat dari adanya 6 jawaban kueosioner yang bahkan mengalami lebih dari 6 gejala.

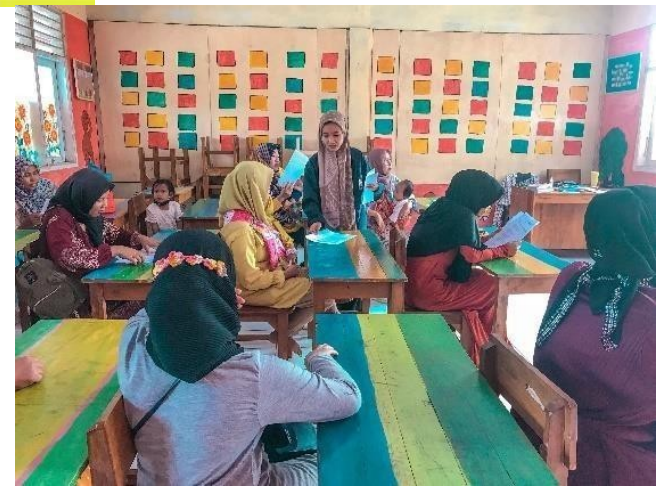

Gambar 1. Pembagian kuesioner

Tahap kedua adalah

wawancara berupa tanya jawab dengan wali murid terkait permasalahan yang terjadi selama menghadapi pembelajaran online. Hasil dari tahap kedua ini diperoleh bahwa mereka tidak mengetahui tentang Dukungan Psikologis Awal (DPA) dan mereka merasa tertekan dengan keadaan pandemi ini dikarenakan berbagai situasi sulit bermunculan seperti hilangnya mata pencaharian, pendapatan yang berkurang, ketidakpastian, tidak siap dalam membagi waktu untuk bekerja di rumah dan mengurus rumah tangga serta mendampingi anak belajar dan bermain. Wali murid berpendapat ibu rumah tangga yang tidak memiliki asisten rumah tangga merasa sulit untuk membagi waktu mengurus rumah tangga dan mendampingi anak belajar online. Akibatnya resiliensi keluarga dalam mengelola sumber daya fisik dan nonfisik tidak optimal. Sementara Keluarga yang tidak resiliensi ketika dihadapi pada situasi sulit dapat memengaruhi kondisi anak baik secara fisik, jiwa maupun dalam perkembangannya (Miskiah, 2020). 


\section{WAHANA DEDIKASI}

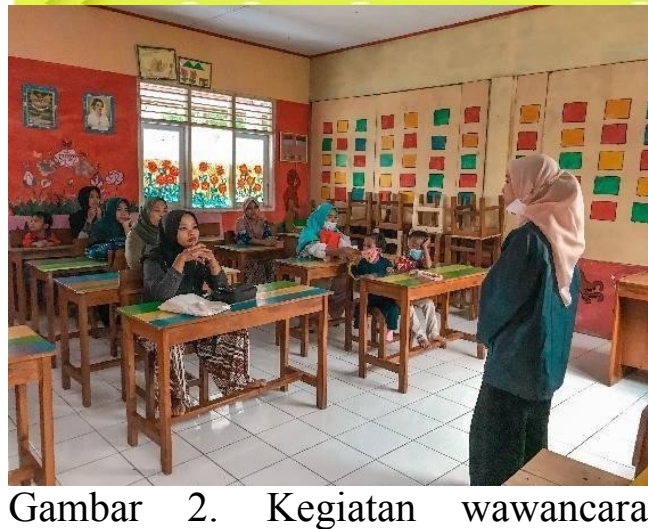

Tahap ketiga yaitu menyampaikan materi lebih dalam seputar pemahaman dukungan psikologis awal (DPA) pada wali murid PAUD dan melakukan diskusi setelah penyampaian materi selesai. Hasil dari tahap ini didapatkan bahwa sebagian wali murid PAUD sebenarnya sudah melakukan dukungan psikologis awal namun hanya pada langkah pertama DPA yaitu mengenali dan memberikan perhatian, mereka dapat mengenali dan mengetahui penyebab mengapa mereka merasa tidak nyaman, mudah tersulut emosi seperti marah tanpa sebab dan merasa kelelahan fisik. Setelah mereka mengetahui penyebabnya mereka membicarakan hal tersebut bersama pasangannya (suami/istri) untuk mencari solusi terkait permasalahan tersebut. Namun langkah kedua DPA yaitu mendengarkan dan langkah ketiga DPA menghubungkan, tidak mereka lakukan. Akibatnya permasalahan tersebut belum dikatakan selesai. Setelah diberikan pemahaman terkait langkah DPA ini wali murid dapat memahami cara melakukan langkah DPA yang selanjutnya yaitu mendengarkan dan menghubungkan. Wali murid pun juga menjadi tahu bagaimana cara mendengarkan anak dengan baik dan benar serta membangun komunikasi positif dan resiliensi keluarga yang optimal. Karena menurut wali murid PAUD DPA ini membantu untuk mengelola diri sendiri agar dapat berperilaku positif dalam mendampingi anak menghadapi pembelajaran online.

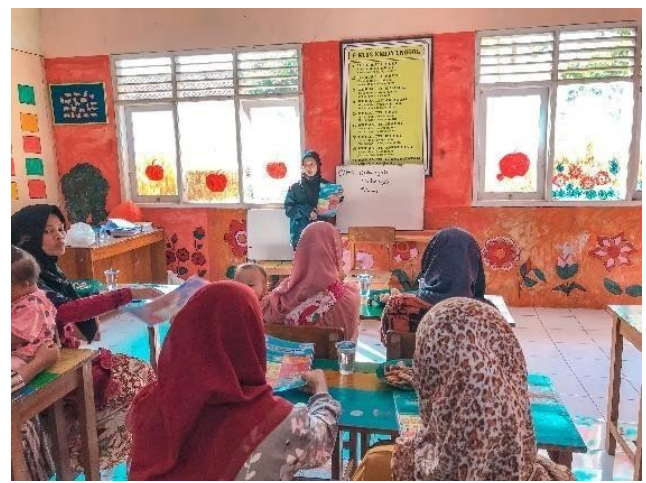

Gambar 3. Pemahaman terkait DPA

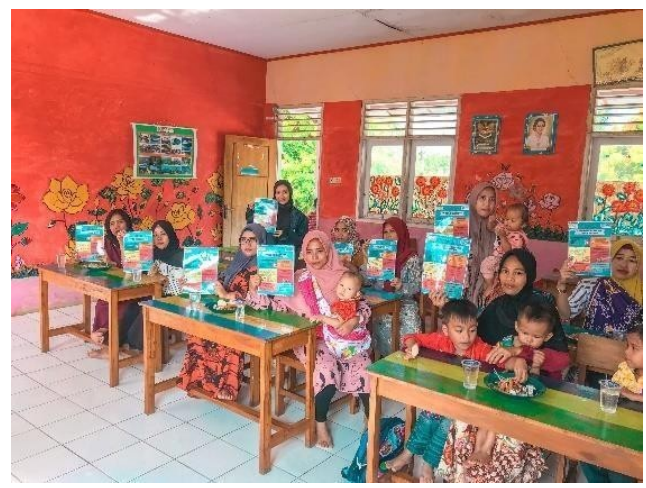

Gambar 4. Pembagian poster DPA

\section{KESIMPULAN}

Berdasarkan hasil yang diperoleh dalam pelaksanaan kegiatan pengabdian kepada masyarakat ini dapat disimpulkan bahwa kegiatan ini telah memberikan kontribusi kepada wali murid PAUD di Desa Curugbarang Kecamatan Cipeucang, yakni keterampilan Dukungan Psikologis Awal (DPA) dalam menghadapi pembelajaran online. Berdasarkan hasil dari kegiatan pengabdian kepada masyarakat ini

\section{Copyright@Lulu Aulia Maulida}




\section{WAHANA DEDIKASI}

dapat disimpulkan bahwa sebagian Jarak Jauh selama pandemi wali murid sudah menerapkan langkah pertama DPA, yaitu mengenali dan memberikan perhatian dan mampu memahami dan menerapkan langkah selanjutnya dalam DPA, yaitu mendengarkan dan menghubungkan. Mengingat situasi sulit yang datang tidak pernah mengenal waktu, tempat, situasi dan kondisi. Oleh karena itu keterampilan DPA selaku wujud memperbaiki situasi lebih baik dibandingkan dengan mengeluh dan meyalahi situasi yang dihadapi, dikarenakan keberanian dalam melewati situasi sulit akan membangun karakter yang tangguh. Orang tua yang tangguh merupakan orang tua yang terampil dalam menyesuaikan diri dengan situasi sulit dan mampu merencanakan langkahlangkah nyata untuk mengendalikan diri dan keluarga. Orang tua seperti ini menjadi sumber kekuatan yang membuat diri dan keluarganya mampu bertahan dalam situasi dan kondisiapa pun. Dengan DPA ini juga akan membantu orang tua dalam mengelola emosinya ketika mendampingi anak selama masa pandemi dalam menghadapi pembelajaran online.

\section{DAFTAR PUSTAKA}

Brooks, J. (2011). The Process of Pareting. (Yogyakarta: Pustaka Belajar)

Bukatko, D and Daehler, M.V, (2012). Child Development A Thematic Approach. (USA: Wadsworth)

Centre, P. (2020). Dukungan Psikologis Awal (Psychological First Aid - PFA) Jarak Jauh selama pandemi COVID-19. Dukungan Psikologis (Psychological First Aid - PFA) 


\section{WAHANA DEDIKASI}

COVID-19,14.

https://ipkindonesia.or.id/medi

a/ 2020/04/Remote-PFA-

IFRC-

Bahasa-Indonesia.pdf

Hanggara Budi Utomo, Vivi Ratnawati, Nora Yuniar Setyaputri, Restu Dwi Ariyanto, \& Widi Wulansari. (2021).

Pengabdian

Masyarak

at Penerapan Dukungan

Psikologis untuk

Meningkatkan Perubahan

Positif Pada Mahasiswa

Selama Pembelajaran

JURPIKAT

Daring.

Pengabdian

(Jurnal

Masyarakat), 2(1), 66-

76.

https://doi.org/10.37339/jurpikat. v2i1.481

Hariadi Ahmad. (2020). Pengaruh

Dukungan Psikologis Awal pada Remaja dalam Pencegahan Covid

- 19 pada Siswa Madrasah Aliyah Al Badriyah. Realita, 5 Nomor 2, 27.

Kementrian Pendidikan dan

Kebudayaan. (2019) Dukungan

Psikologis Awal Bimbinan

Teknis Calon Fasilitator

Pendidikan keluarga dalam

Jaringan. Jakarta

Kementerian Pendidikan dan

Kebudayaan. (2020). Mengenal

Dukungan Psikologi Awal Bagi

Orang Tua Anak Usia Dini

(Muhammad Hasbi (ed.)).

Direktorat Pendidikan Anak

Usia Dini, Kemendikbud-RI.

Miskiah. (2020).

Ketahanan

60 | Wahana Dedikasi

Copyright@Lulu Aulia Maulida
(Resilience) Keluarga di Masa Pandemi. Ketahanan (Resilience) Keluarga di Masa Pandemi, 12. https://bdkpalembang.kemenag.g o.id/upload/files/Web juni_21.pdf

Muhammad, H. (2020). Media Daring (tutorial webex, zoom, dan 


\section{W/AHANA DEDIKASI}

google drive).

Ulfah Fajarini Prof. Dr. MSi. (2020).

Bahan Seminar "Peran Orang

Tua Saat Mendampingi Anak

Belajar di Rumah Selama WFH

(Work From Home) Agar

Berperilaku Positif 